\title{
Pengembangan Gerak dan Lagu Untuk Menstimulus Kemampuan Berbicara Anak Usia 4-5 Tahun
}

\author{
Tika Putri Wahyuningtyas', ${ }^{1}$ Retno Tri Wulandari ${ }^{2}$, Wuri Astuti ${ }^{3}$ \\ Universitas Negeri Malang ${ }^{1,2,3}$ \\ Email: putri199839@gmail.com
}

\begin{abstract}
ABSTRAK:
Tujuan penelitian pegembangan untuk menghasilkan produk berupa gerak dan lagu yang dapat menstimulus kemampuan berbicara sesuai dengan karakteristik anak usia 4-5 tahun. Metode penelitian yang digunakan adalah penelitian pengembangan model pengembangan Dick and Carey yang dimodifikasi dengan menggunakan sembilan langkah pengembangan. Data yang dikumpulkan menggunakan teknik observasi, kuesioner serta wawancara. berdasarkan pengumpulan data tersebut meghasilkan data berupa data kuantitatif dan kualitatif. Hasil penelitian pengembangan yang melalui validasi ahli yang diperoleh bahwa gerak dan lagu "Sekolahku" sebanyak 91,7 \% anak senang dan 93,6\% anak mudah untuk dilakukan dalam pembelajaran dan dapat menstimulus kemampuan berbicara anak usia 4-5 tahun. Berdasarkan data yang diperoleh dalam penelitan ini gerakdan lagu dapat dikatakan valid dan dapat digunakan dalam pembelajaran bahasa terkait menstimulus kemampuan berbicara anak usia 4-5 tahun.
\end{abstract}

Kata kunci: Pengembangan Gerak dan Lagu; Kemampuan Berbicara; Anak Usia 4-5 tahun

\begin{abstract}
:
The purpose of development research is to produce products in the form of music and movement that can stimulate speaking ability accordance with the characteristics of children 4-5 years. The research method used the research development of the modified Dick and Carey development model using nine step of development. Data collected using observation, questionnaires and interview techniques. Based on the data collection produces data in the form of quantitative and qualitative data. The results of development research through expert validation obtained that the music and movement of "My School" as much 91,7\% of children are happy and 93,6\% of children are easy to do in learning and can stimulate the speaking ability of children 4-5 year. Based on data obtained in this research the music and movement valid and used in language learning related to stimulating the speaking abilty of children 4-5 years.
\end{abstract}

Keywords: Development Music And Movement; Speaking Ablility; Children 4-5 Years

\section{PENDAHULUAN}

Kemampuan berbicara sangat penting bagi anak agar dapat melakukan aktvitas dengan baik. Komunikasi dapat dilakukan melalui berbagai macam cara baik bahasa verbal maupun bahasa tubuh atau gerak. Kegiatan bermain anak akan merasa terkucilkan atau terjadi perkelahian apabila mengalami kesulitan berbicara karena tidak mampu berkomunikasi dengan baik. Anak yang mengalami permasalahan kemampuan berbicara juga akan mempengaruhi pendidikan anak. Menurut Suhartono (2005) berbicara adalah suatu penyampaian maksud tertentu dengan mengucapkan bunyi-bunyi bahasa supaya bunyi tersebut dapat dipahami oleh orang lain dan mendengar di sekitarnya. Kegiatan gerak anak dapat menunjukkan bagaimana perasaan anak (Donvley, 2014). Perkembangan kemampuan berbicara anak yang terganggu juga akan mempengaruhi kegiatan 
anak dengan teman-temannya. Harris (2011) berpendapat gerakan adalah respons nonverbal bagi anak-anak yang belum memiliki kemampuan bahasa. Kegiatan dalam bergerak juga dapat termasuk dalam bentuk komunikasi pada anak. Anak akan kesulitan untuk bertanya tentang apa yang tidak diketahuinya bahkan anak akan sulit dalam menjawab pertanyaan sederhana. Hal tersebut dapat terjadi apabila anak tidak diberi stimulus dengan baik. Anak dapat diberikan stimulus oleh guru melalui pembelajaran.

Pemberlajaran pada aspek perkembangan bahasa yang termasuk didalamya adalah kemampuan berbicara anak. Kemampuan berbicara anak usia dini memiliki standar capaian yang menjadi tujuan dalam pembelajaran. Berdasarkan permendikbud nomor 137 tahun 2014, tingkat pencapaian perkembangan berbicara anak usia empat sampai lima tahun antara lain: Mengulang kalimat sederhana, bertanya dengan kalimat yang benar, menjawab pertanyaan sesuai pertanyaan, mengungkapkan perasaan dengan kata sifat (baik, senang, nakal, jelek, dsb), menyebutkan kata-kata yang dikenal, mengutarakan pendapat pada orang lain, menyatakan alasan terhadap sesuatu yang diinginkan atau ketidak setujuan, menceritakan kembali cerita/dongeng yang pernah di dengar, memperkaya perbendaharaan kata, berpartisipasi dalam percakapan. Kemampuan berbicara sangat penting bagi anak agar dapat melakukan aktvitas dengan baik Secara umum tujuan pengembangan bicara anak usia dini yaitu agar anak mampu mengungkapkan isi hatinya berupa pendapat maupun sikap bahkan secara lisan dengan lafal yang tepat untuk kepentingan komunikasi. Pentingnya kemampuan berbicara sehingga diperlukannya stimulus pada usia dini. Stimulus dapat dilakukan melalui pembelajaran pada anak usia dini.

Berdasarkan wawancara dan observasi pada kelompok A di TK Madani 2 dan TK Dharma Persatuan Bedali. Secara keseluruhan anak memiliki kekurangan pemahaman tentang penjelasan materi yang diberikan oleh guru meskipun telah diberikan contoh konkrit serta penjelasan berulang, seperti saat pemberian materi tentang tema sayuran anak masih kesulitan untuk menjawab pertanyaan sederhana yang diberikan. Faktor penyebab dari permasalahan tersebut yaitu anak masih kesulitan dalam mengekspresikan gagasan, pemikiran atau ide, anak kesulitan memahami makna kata baru, dan dalam pembelajaran terasa membosankan bagi anak. Pembelajaran dapat berjalan dengan lebih bermakna pada anak dalam keadaan suasana yang menarik minat anak dan menyenangkan. Kegiatan yang menyenangkan bagi anak salah satunya melalui gerak dan lagu.

Menurut Wulandari dan Anisa (2019) gerak dan lagu yang diberikan untuk anak usia dini adalah bentuk gerak sederhana, tempo / ritme gerakan tidak terlalu cepat, temanya menyesuaikan dengan perkembangan anak, suasananya bahagia dan lincah.Berfokus pada gerakan dan teknik menyanyi lagu yang dilakukan anak. Pengembangan intonasi musik, dilakukan atas dasar persepsi aktif terhadap musik yang mengandung informasi musik emosional dan imajinatif, komunikatif, motorik, visual, pengalaman produktif, memberikan pengaruh luar biasa pada pengembangan hubungan emosional dan nilai kepada dunia, dan aktualisasi potensi pribadi setiap anak (Volchegorskaya \& Nogina, 2014). Bernyanyi pada anak usia dini merupakan metode pembelajaran yang dekat dengan anak 
dikarenakan anak usia dini aktif dalam bergerak. Keterlibatan sensorik motor banyak yang aktif dalam suatu kegiatan, semakin tinggi tingkat keberhasilan dalam belajar dan menyimpan informasi serta pengetahuan. Ketika anak menyaksikan dan mendengarkan lagu tanpa disadari anak akan melakukan gerakan sesuai irama dan memahami kosakatanya.

Hal tersebut terlihat ketika anak mendengarkan lagu anak akan bergerak lebih cepat dan kuat saat irama semakin cepat. Anak akan senang berlarian dan memukul meja sambil bersenandung. Kegiatan gerak dan lagu dapat membuat anak bergerak sesuai irama dan ekspresif. Berdasarkan penelitian terdahulu oleh Rachmawati pada tahun 2016 menyatakan bahwa kegiatan gerak dan lagu efektif untuk meningkatkan kemampuan bahasa anak usia 5-6 tahun dengan judul lagu Hati Gembira. Berdasarkan hal tersebut peneliti melakukan penelitian pengembangan gerak dan lagu untuk menstimulus kemampuan berbicara anak usia 4-5 tahun.

\section{METODE}

Pengembangan yang digunakan peneliti untuk pengembangan gerak dan lagu Sekolahku untuk menstimulus kemampuan berbicara anak usia 4-5 tahun di kelompok A di TK. Metode penelitian dan pengembangan ( $\mathrm{R} \& \mathrm{D}$ ) yang digunakan adalah model pengembangan menurut Dick and Carey (dalam Setyosari:2013) yang memiliki sepuuh langkah pengembangan yang kemudian dimodifikasi menjadi sembilan langkah karena keterbatasan waktu penelitian. Langah-langkah penelitian pengembangan sebagai berikut:

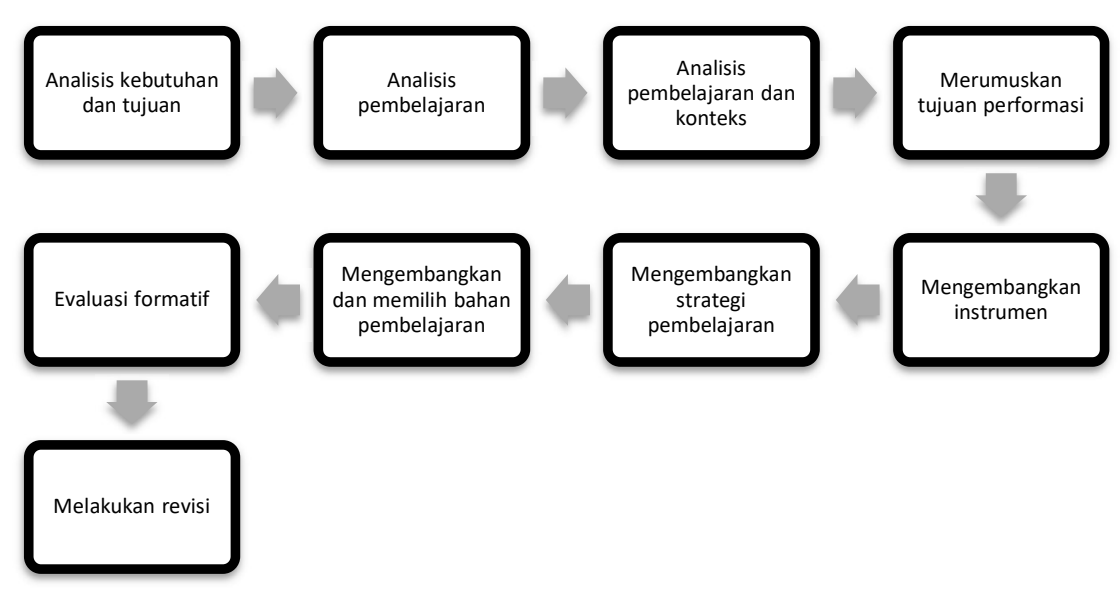

Gambar 1. Alur Penelitian Pengembangan

Pengumpulan data dalam penelitian "Pengembangan Materi Gerak dan Lagu untuk Menstimulus Kemampuan Berbicara Anak Usia 4-5 Tahun" menggunakan lembar wawancara dan lembar observasi digunakan untuk mengumpulkan data kualitatif dari proses dan hasil pada saat pembelajaran berlangsung untuk analisis kebutuhan. Pengolahan data berupa analisis kualitatif 
juga dilakukan untuk menganalisis kumpulan hasil saran pada kuesioner dari para ahli serta tanggapan dari guru setelah dilakukan uji coba produk. Instrumen kuisioner juga digunakan untuk mengumpulkan data kuantitatif dari para ahli. Data yang diperoleh dari yaitu ahli seni tari anak usia dini, ahli seni musik bahasa anak usia dini, ahli pembelajaran bahasa anak usia dini, dan ahli pengguna yaitu guru. Analisis kuantitatif digunakan untuk menilai presentase yang diperoleh dari data uji coba perorangan, uji coba kelompok kecil, dan uji coba kelompok besar. Data persentase, proporsi maupun raiso, maka kesimpulan yang dapat diambil disesuaikan dengan permasalahan. Berikut ini penggolongan persentase kategori yang akan digunakan adalah (Akbar, 2016)) :

Tabel. 1 Kriteria pencapaian

\begin{tabular}{|c|c|l|}
\hline No & Kriteria pencapaian nilai & \multicolumn{1}{|c|}{ Tingkat validitas } \\
\hline 1 & $81,0 \%-100,00 \%$ & $\begin{array}{l}\text { Sangat valid,sangat efektif, sangat tuntas, dapat } \\
\text { digunakan tanpa perbaikan }\end{array}$ \\
\hline 2 & $61,0 \%-80,0 \%$ & $\begin{array}{l}\text { Cukup valid,cukup efektif, cukup tuntas, dapat digunakan } \\
\text { namun perlu perbaikan kecil }\end{array}$ \\
\hline 3 & $41,0 \%-60,0 \%$ & $\begin{array}{l}\text { Kurang valid, kurang efektif, atau kurang tuntas, perlu } \\
\text { perbaikan besar, disarankan tidak dipergunakan }\end{array}$ \\
\hline 4 & $21,0 \%-40,0 \%$ & $\begin{array}{l}\text { Tidak valid, tidak efektif, tidak tuntas, tidak bisa } \\
\text { digunakan }\end{array}$ \\
\hline 5 & $00,00 \%-20,0 \%$ & $\begin{array}{l}\text { Sangat tidak valid, sangat tidak efektif, sangat tidak } \\
\text { tuntas, tidak bisa digunakan }\end{array}$ \\
\hline
\end{tabular}

\section{HASIL DAN PEMBAHASAN}

\section{Hasil}

Hasil dari penelitian yang diperoleh dari penelitian pengembangan gerak dan lagu "Sekolahku", hasil data tinjauan para ahli pengembang, hasil uji coba perorangan, hasil dari uji coba kelompok kecil, dan hasil uji coba lapangan atau uji coba kelompok besar. Pengembangan gerak dan lagu ini data validasi yang diperoleh melalui pengisian kuesioner oleh ahli seni tari divalidasi diperoleh data sebagai berikut:

Tabel. 1 Data Hasil Evaluasi Ahli Seni Tari Anak Usia Dini

\begin{tabular}{|c|c|c|c|c|}
\hline \multirow[t]{2}{*}{ No } & \multirow[t]{2}{*}{ Aspek yang Dinilai } & \multicolumn{2}{|c|}{$\begin{array}{c}\text { Alternatif } \\
\text { Jawaban }\end{array}$} & \multirow[t]{2}{*}{ Persentase } \\
\hline & & Tse & Tsh & \\
\hline B & $\begin{array}{l}\text { Kerakteristik gerak terkait } \\
\text { tentang gerak dan lagu } \\
\text { "Sekolahku" }\end{array}$ & 39 & 40 & $97,5 \%$ \\
\hline
\end{tabular}

Berdasarkan kriteria pencapaian maka persentase yang diperoleh sebanyak $97,5 \%$, jumlah data tersebut masuk kedalam kategori valid dan dapat digunakan. 
Jurnal Golden Age, Universitas Hamzanwadi

Vol. 04 No. 1, Juni 2020, Hal. 80-89

E-ISSN : 2549-7367

Data yang diperoleh melalui pengisian kuesioner oleh ahli seni musik anak usia dini diperoleh data sebagai berikut:

Tabel. 2 Data Hasil Evaluasi Ahli Seni Musik Anak Usia Dini

\begin{tabular}{ccccc}
\hline \multirow{2}{*}{ No } & Aspek yang Dinilai & \multicolumn{2}{c}{$\begin{array}{c}\text { Alternatif } \\
\text { Jawaban }\end{array}$} & Persentase \\
\cline { 3 - 5 } B & & Tse & Tsh & \\
\hline 1. & $\begin{array}{l}\text { Kerakteristik lagu terkait } \\
\text { tentang gerak dan lagu } \\
\text { "Sekolahku" }\end{array}$ & 33 & 40 & $82,5 \%$. \\
\hline
\end{tabular}

Berdasarkan kriteria pencapaian dengan nilai persentase sebesar 82,5\% maka data tersebut masuk kedalam kategori valid dan dapat digunakan. Data kualitatif yang diperoleh berupa saran yaitu disarankan syair pada bait kedua lebih baik diganti dan diberi penambahan lirik. Data validasi yang diperoleh melalui pengisian kuesioner oleh ahli pembelajaran bahasa anak usia dini diperoleh data sebagai berikut:

Tabel. 3 Data Hasil Evaluasi Ahli Pembelajaran Bahasa Anak Usia Dini

\begin{tabular}{lccccc}
\hline & No & Aspek yang Dinilai & \multicolumn{2}{c}{$\begin{array}{c}\text { Alternatif } \\
\text { Jawaban }\end{array}$} & Persentase \\
\cline { 3 - 5 } & & & Tse & Tsh & \\
\hline B & 1. & $\begin{array}{l}\text { Tingkat capaian berbicara } \\
\text { terkait tentang gerak dan } \\
\text { lagu "Sekolahku" }\end{array}$ & 38 & 40 & $95 \%$. \\
\hline
\end{tabular}

Berdasarkan kriteria pencapaian dengan nilai persentase sebesar 95\%. maka data tersebut masuk kedalam kategori valid dan dapat digunakan. Data validasi yang diperoleh melalui pengisian kuesioner oleh ahli pengguna pada pembelajaran anak usia dini oleh Suryati sebagai pengguna selaku guru Kelompok A di TK Islam Insan Cita dengan nilai persentase sebesar 92,5 \%.

Tabel. 4 Data Hasil Evaluasi Ahli Pengguna pada Pembelajaran Anak Usia Dini

\begin{tabular}{|c|c|c|c|c|c|}
\hline \multirow{2}{*}{\multicolumn{2}{|c|}{$\mathrm{B}$}} & \multirow[t]{2}{*}{ Aspek yang Dinilai } & \multicolumn{2}{|c|}{$\begin{array}{l}\text { Alternatif } \\
\text { Jawaban }\end{array}$} & \multirow[t]{2}{*}{ Persentase } \\
\hline & & & Tse & Tsh & \\
\hline $\begin{array}{l}\text { sark } \\
\text { an } \\
\text { krit }\end{array}$ & 1. & $\begin{array}{l}\text { Kesesuain gerak dan lagu } \\
\text { terkait tentang gerak dan } \\
\text { lagu "Sekolahku" }\end{array}$ & 37 & 40 & $92,5 \%$ \\
\hline
\end{tabular}

eria

pencapaian maka data tersebut masuk kedalam kategori valid dan dapat digunakan. Data kualitatif yang diperoleh berupa saran yaitu dapat mempertahankan kesesuaian tema pada gerak dan lagu dan lirik lagu dapat diulang sampai 2 kali agar durasi lagu lebih panjang sehingga lebih bermakna 
Jurnal Golden Age, Universitas Hamzanwadi

Vol. 04 No. 1, Juni 2020, Hal. 80-89

E-ISSN : 2549-7367

bagi anak. Secara umum data yang berupa hasil evaluasi menurut para ahli dan pengguna diperoleh sebagai berikut:

Tabel. 5 Data Rata-Rata Hasil Evaluasi Para Ahli

\begin{tabular}{ccl}
\hline No. & \multicolumn{1}{c}{ Validasi Ahli } & \multicolumn{1}{c}{ Persentase } \\
\hline 1 & Ahli Pembelajaran Seni Tari Anak Usia Dini & $97,5 \%$ \\
\hline 2 & Ahli Pembelajaran Seni Musik Anak Usia Dini & $82,5 \%$ \\
\hline 3 & Ahli Pembelajaran Bahasa Anak Usia Dini & $95 \%$ \\
\hline 4 & Ahli Pengguna pada Pembelajaran Anak Usia Dini & $92,5 \%$ \\
\hline & Rata-Rata & $91,87 \%$ \\
\hline
\end{tabular}

Berdasarkan rata-rata keseluruhan yang diperoleh dari para ahli, kesimpulan yang diperoleh dalam bentuk persentase sebesar 91,87\%. Hal tersebut termasuk kedalam kriteria pencapaian dengan tingkat validitas sangat valid,sangat efektif, sangat tuntas, dapat digunakan tanpa perbaikan. Kesimpulan yang diperoleh berdasarkan data tersebut bahwa gerak dan lagu yang berjudul "Sekolahku" dapat digunakan dalam pembelajaran anak untuk menstimulus kemampuan berbicara anak usia 4-5 tahun.

\section{Hasil Uji Coba}

Pada data uji coba yang dilakukan pada anak usia 4-5 tahun di kelompok A TK Dharma Wanita Persatuan 06 Bedali dan TK Islam Insan Cita hasil dari kesuluruhan data yang diperoleh dari uji coba dalam aspek kemudahan diperoleh sebagai berikut:

Tabel. 6 Data Hasil Uji Coba Aspek Kemudahan

\begin{tabular}{cccc}
\hline \multirow{2}{*}{ No. } & Uji Coba & \multicolumn{2}{c}{ Persentase } \\
\cline { 3 - 4 } & & $100 \%$ & Tidak \\
\hline 1 & Uji Coba Perorangan & $93,3 \%$ & $0 \%$ \\
\hline 2 & Uji Coba Kelompok Kecil & $87,5 \%$ & $6,7 \%$ \\
\hline 3 & Uji Coba Kelompok Besar & $93,6 \%$ & 12,5 \\
\hline & Rata-Rata & $6,4 \%$ \\
\hline
\end{tabular}

Hasil kesuluruhan data yang diperoleh dari uji coba dalam aspek kesenangan diperoleh sebagai berikut:

Tabel. 7 Data Hasil Uji Coba Aspek Kesenangan

\begin{tabular}{cccc}
\hline \multirow{2}{*}{ No. } & Uji Coba & \multicolumn{2}{c}{ Persentase } \\
\cline { 3 - 4 } & & Ya & Tidak \\
\hline 1 & Uji Coba Perorangan & $100 \%$ & $0 \%$ \\
\hline
\end{tabular}


Jurnal Golden Age, Universitas Hamzanwadi

Vol. 04 No. 1, Juni 2020, Hal. 80-89

E-ISSN : 2549-7367

\begin{tabular}{cccc}
\hline 2 & Uji Coba Kelompok Kecil & $100 \%$ & $0 \%$ \\
\hline 3 & Uji Coba Kelompok Besar & $91,6 \%$ & $8,4 \%$ \\
\hline Rata-Rata & $91,6 \%$ & $8,4 \%$
\end{tabular}

Dari tabel. 3 diperoleh persentase bahwa sebanyak 91,6 \% anak senang melakukan gerak dan lagu "Sekolahku". Data kedua yang terdapat pada tabel. 2 diperoleh adalah 93,6\% anak pada pembelajaran gerak dan lagu "Sekolahku" mudah dilakukan oleh Kelompok A di TK Dharma Wanita Persatuan 06 Bedali dan TK Islam Insan Cita.

\section{PEMBAHASAN}

Menurut pendapat Susanto dan Suhartono bahwa kemampuan berbicara anak yaitu kemampuan dalam mengungkapkan apa yang diinginkan serta diperlukan untuk berkomunikasi dengan orang lain. Komunikasi diperlukan anak untuk beradaptasi di lingkungan terutama di lingkungan sekolah anak. Lingkungan sekolah juga berperan untuk menstimulus hal tersebut dengan kegiatan yang menyenangkan dan bermakna bagi anak. Anak usia dini memiliki karakteristik yang aktif dalam bergerak. Anak akan bergerak sesuai dengan suasana hatinya atau dengan melihat sekitarnya. Kegiatan bernyanyi dan juga dapat mengembangakan berbagai macam aspek perkembANgAn. Hal tersebut juga menjadikan kegiatan gerak dan lagu harus disesuikan dengan karakteristik anak usia dini seperti gerak untuk anak bersifat sederhana, bertema, memiliki makna, dan gerakan yang biasa ditirukan oleh anak baik gerakan yang ditiru pada orang tua atau binatang Kamtini dan Tanjung (2005). Karakteristik lagu tidak jauh berbeda untuk anak usia dini yaitu bermakna,memiliki tema, melodi sederhana dan mudah diingat oleh anak Rachmi (2010).

Penelitian pengembangan gerak dan lagu untuk menstimulus kemampuan berbicara anak usai 4-5 tahun dilakukan pada 25 anak kelompok A yang berada di TK Dharma Wanita Persatuan 06 Bedali dan TK Islam Insan Cita. Peneliti melakukan studi pendahuluan dengan menggunakan teknik pengambilan data berupa wawancara dengan guru kelas dan melakukan observasi yang digunakan untuk dijadikan data awal. Data awal diperlukan untuk dilakukannya analisis kebutuhan dan tujuan untuk mengetahui permasalahan dilapangan dan yang dibutuhkan untuk mengatasi hal tersebut untuk mencapai tujuan, juga dapat digunakan untuk analisis pembelajaran serta pembelajaran dan konteks pada tahap selanjutnya sehingga mampu mengetahui proses, prosedur dan tugas-tugas belajara anak dan karakteristik anak usia 4-5 tahun serta dapat mengumpulkan data penelitian terdahulu sebagai dukungan dalam pembuatan produk sehingga mengetahui kebereadaan peneliti sebagai pengembang suatu produk.

Pengembangan dilakukan dengan merumuskan tujuan performasi produk berdasarkan tingkat capaian perkembangan anak usia 4-5 tahun. Rumusan tujuan yang dilakukan sesuai tingkat capaian perkembangan pada Standar PAUD Peraturan Menteri Pendidikan Dan Kebudayaan No.137 Tahun 2014 yang disesuaikan dengan kegiatan pembelajaran yaitu mengungkapkan perasaan dengan kata sifat (baik, senang, nakal, jelek dsb), mengulang kalimat sederhana dan 
menjawab pertanyaan sesuai pertanyaan. Penenelitian pengembangan gerak dan lagu "Sekolahku" pada tahap pengembangan instrumen yang bertujuan untuk melihat kelayakan produk. Produk perlu dinilai dengan instrumen yang digunakan untuk uji coba pengembang yaitu pada ahli pembelajaran seni tari anak usia dini, ahli pembelajaran seni musik anak usia dini, ahli pembelajaran bahasa anak usia dini dan ahli pengguna pada pembelajaran anak usia dini. Instrumen penilaian yang digunakan pada uji coba perorangan, uji coba kelompok kecil dan uji coba kelompok besar. Hasil validasi digunakan untuk mengetahui kelayakan produk ditinjau dari aspek kemudahan, kesenangan, dan kevalidan. Masukan dan saran dari para ahli dan pengguna digunakan sebagai bahan perbaikan dan revisi produk. Berdasarkan tahap sebelumnya peneliti mengembangkan dan memilih bahan pembelajaran untuk mestimulasi kemampuan berbicara anak usia 4-5 tahun dengan gerak dan lagu "Sekolahku".

Uji coba produk dilakukan untuk memperoleh data untuk mengetahui kelayakan produk. Produk terlebih dahulu di validasi oleh para ahli pengembang yaitu ahli pembelajaran seni tari anak usia dini diperoleh data berupa saran yaitu pada buku panduan produk gerak dan lagu untuk mendeskripsikan hitungan secara lebih rinci tentang arah agar lebihh mudah untuk dipahami. Berdasarkan validasi ahli pembelajaran seni musik anak usia dini diperoleh saran yaitu pada bagian syair pada bait kedua lebih baik diganti dan diberi penambahan lirik. Ahli pembelajaran bahasa anak usia dini diperoleh berupa saran yaitu font size pada buku panduan diperbesar dan pemilihan kata lebih oprasional, penambahan lirik tentang guru dan suasana belajar yang dapat ditambahkan di syair pada bagian reff dengan menambahkan lirik dan tempo dipercepat untuk menggambarkan keceriaan. Berdasarkan ahli pengguna pada pembelajaran anak usia dini diperoleh berupa saran yaitu dapat mempertahankan kesesuaian tema pada gerak dan lagu dan lirik lagu dapat diulang sampai 2 kali agar durasi lagu lebih panjang sehingga lebih bermakna bagi anak .

Data hasil validasi yang diperoleh dalam bentuk persentase dari ahli seni tari anak usia dini, ahli pembelajaran seni musik anak usia dini, ahli pembelajaran bahasa anak usia dini, dan ahli pengguna pada pembelajaran anak usia dini dengan jumlah rata-rata keseluruhan sebanyak 91,87\% dengan tingkat validitas sangat valid,sangat efektif, sangat tuntas, dapat digunakan tanpa perbaikan. Berdasarkan uji coba yang dilakukan diperoleh presentase masing-masing uji coba yaitu uji coba perorangan, uji coba kelompok kecil, dan uji coba kelompok besar secara keseluruhan diperoleh persentase sebanyak 93,6 \% anak mudah melakukan kegiatan gerak dan lagu "Sekolahku". Data yang diperoleh aspek kesenangan pada uji coba perorangan, uji coba kelompok kecil, dan uji coba kelompok besar secara keseluruhan diperoleh diperoleh persentase bahwa sebanyak 91,6 \% anak senang melakukan gerak dan lagu "Sekolahku".

\section{KESIMPULAN}

Berdasarkan hasil penelitian pengembangan dapat disimpulkan bahwa gerak dan lagu "Sekolahku" valid dan layak untuk digunakan menurut para ahli 
pengembang dan hasil uji coba. Gerak dan lagu hasil perbaikan atas saran para ahli dan pengguna berupa gerak dan lagu, pada buku panduan hitungan gerak menjadi lebih deskriptif sehingga lebih mudah untuk dimengerti oleh pembaca. Syair pada gerak dan lagu pada bait kedua memiliki perubahan dan penambahan lirik pada bagian reff. Perubahan tentang lingkungan dengan lirik "tidak ada sampah disini" dan pembahan lirik tentang suasana belajar anak dan terkait guru sebanyak dua baris sehingga materi pengetahuan anak dapat lebih bervariasi. Gerak dan lagu juga diperpanjang menjadi dua kali pengulangan sehingga lebih bermakna bagi anak. Gerak dan lagu "sekolahku" dapat digunakan dalam pembelajaran untuk menstimulus kemampuan berbicara anak usia 4-5 tahun. Penggunaan gerak dan lagu ini dapat membuat pembelajaran anak lebih aktif dan menyenangkan saat dilakukan karena telah sesuai dengan karakteristik anak usia 4-5 tahun. Disarankan untuk penelitian selanjutnya dapat meneliti tingkat keefektifan dari gerak dan lagu "Sekolahku"

\section{DAFTAR PUSTAKA}

Akbar, Sa'dun. 2016. Instrument Perangkat Pembelajaran. Bandung: Pt.Remaja Rosdakarya

Aswasulasikin, A., \& Nur, H. Z. (2018). Pengembangan Media Pembelajaran Hts (Hang Of The Scramble) Pada Mata Pelajaran Ipa Siswa Kelas Iii Sdn 03 Sambelia. Jurnal Didika: Wahana Ilmiah Pendidikan Dasar, 4(2), 50-57.

Basyiroh, I. (2018). Program Pengembangan Kemampuan Literasi Anak Usia Dini. Tunas Siliwangi: Jurnal Program Studi Pendidikan Guru Paud Stkip Siliwangi Bandung, 3(2), 120-134.

Harris, D. J. 2011. Shake, Rattle And Roll - Can Music Be Used By Parents And Practitioners To Support Communication, Language And Literacy Within A Pre-School Setting? Education 3-13, 39(2), 139-151. Https://Doi.Org/10.1080/03004270903232691

Hardianti, F. (2019). Alat Permainan Edukatif Scrabble Untuk Meningkatkan Kemampuan Membaca Permulaan Anak Kelompok B. Jurnal Golden Age, 3(01), 17-29.

Ilhami, B. S., Fitri, B. F. H., \& Ramdhani, S. (2019). Permainan Kuda Bisik Untuk Meningkatkan Kemampuan Pembendaharaan Kosakata Anak Usia 56. Cakrawala Dini; Jurnal Pendidikan Anak Usia Dini, 10(2), 101-108.

Kamitini \& Tanjung. 2005. Bermain Melalui Gerak Dan Lagu Di Taman KanakKanak. Jakarta: Departemen Pendidikan Nasional Direktorat Jendral Pendidikan Tinggi

Maulidian, M., Suhirman, S., \& Ramdani, Z. (2019). Permainan Kartu Gambar Dengan Metode Cantol Roudhoh Di Kelompok B Tk Mahkota Selong. Jurnal Golden Age, 3(01), 57-64. 
Nahdi, K., \& Yunitasari, D. (2019). Literasi Berbahasa Indonesia Usia Prasekolah Ancangan Metode Dia Tampan Dalam Membaca Permulaan. Jumal Obsesi: Jumal Pendidikan Anak Usia Dini, 4(1), 446-453.

Nahdi, K., \& Yunitasari, D. (2019a). Inside-Outside Circle: An Early Childhood Language And Literacy Development Method. International Journal Of Innovation, Creativity And Change, 5(6), 325-335.

Najamuddin, N., \& Hidayaturrahman, H. (2017). Pengaruh Media Audio Visual Terhadap Penguasaan Kosakata Anak Kelompok B Ra Al-Hasaniyah Nw Jenggik. Jurnal Golden Age, 1(01), 56-63.

Rachmawati, Diana. 2016. Pengembangan Gerak Dan Lagu Untuk Pembelajaran Bahasa Anak Kelompok B Di Tk Satu Atap Sdn Tanjungrejo 5 Malang: Skripsi

Rachmi, Dkk.2010. Keterampilan Musik Dan Tari. Jakarta : Universitas Terbuka

Setyosari.2013.Metode Penelitian Pendidikan Dan Pengembangan. Jakarta: Pt Fajar Interpratama Mandiri

Suhartono.2005.Pengembangan Keterampilan Bicara Anak Usia Dini. Jakarta: Departemen Pendidikan Nasional

Donlevy, L. 2014. My Teacher Story: Row, Row, Row Your Boat. Education Matters, 2(2), 9.

Volchegorskaya, E., \& Nogina, O. 2014. Musical Development In Early Childhood. Procedia - Social And Behavioral Sciences, 146, 364-368. Https://Doi.Org/10.1016/J.Sbspro.2014.08.113

Widhianawati, N. (2011). Pengaruh Pembelajaran Gerak Dan Lagu Dalam Meningkatkan Kecerdasan Musikal Dan Kecerdasan Kinestetik Anak Usia Dini. Edisi Khusus, 2(2011), 220-228.

Wulandari, R. T., \& Anisa, N. 2019. Development Of Thematic-Based Motion And Song Learning Videos To Stimulate Work: Art Of Kindergarten Teacher's Ability. Universal Journal Of Educational Research, 7(12a), 2734. Https://Doi.Org/10.13189/Ujer.2019.071904 